\title{
Endüstri 4.0 Döneminde Entelektüel Sermaye: Bilişim Sektörü Üzerine Bir Araştırma
}

\section{Intellectual Capital in the Period of Industry 4.0: A Research on the Information Sector}

\author{
İlknur Ergün ${ }^{1} \oplus$, İrem Özcan² ${ }^{\circledR}$ \\ 'Öğr. Görevlisi Dr., Tekirdağ Namık Kemal Üniversitesi, Muratlı Meslek Yüksekokulu, Yönetim ve Organizasyon Bölümü, \\ İşletme Yönetimi Programı, Tekirdağ, Türkiye. \\ E-posta: iergun@nku.edu.tr \\ ${ }^{2}$ Dr. Öğr. Üyesi, Haliç Üniversitesi, İşletme Fakültesi, İşletme Bölümü, İstanbul, Türkiye. \\ E-posta: iremozcan@halic.edu.tr \\ ORCID: İ.E. 0000-0002-4958-4815; İ.0̈. 0000-0002-0991-3848
}

\section{ÖZ}

Çağımızda yaşanan dijital dönüşüm, bilişim teknolojilerini kullanarak faaliyet gösteren işletmelerin sayısını ve etkinliğini önemli ölçüde arttırmıştır. Bilişim sektöründe faaliyet gösteren bu işletmelerin defter değeri ile piyasa değeri arasındaki fark entelektüel sermaye olarak açılanmaktadır. Çalışmanın amacı, Borsa İstanbul (BİST) bilişim sektöründe işlem gören işletmelerin entelektüel sermayelerinin oluşup oluşmadığını tespit ederek, tutarını ölçmektir. Türkiye'de 2018 yılından itibaren Endüstri 4.0 yol haritasının oluştuğu ve işletmelerin bu konudaki farkındalıklarının arttığı düşünülerek, işletmelerin 2018, 2019, 2020 yıllarına ait finansal tablo verileri, hesaplanmış maddi olmayan değer yöntemi ile analiz edilmiştir. Analize konu olan 18 işletmenin 3'ü yöntemin gerektirdiği şartları sağlamadığından analiz dışı bırakılmış ve 15 işletme için entelektüel sermaye değeri hesaplanabilmiştir. Elde edilen sonuçlar önceki çalışmalar ile karşılaştırıldığında, bilişim sektöründe, entelektüel sermaye değerinin önemli ölçüde artış gösterdiği tespit edilmiştir. Bu değişimde Endüstri 4.0 uygulamalarında entelektüel sermayenin katkısının artmasının etkili olduğu sonucuna varılmıştır. Anahtar kelimeler: Endüstri 4.0, Entelektüel Sermaye, Hesaplanmış Maddi Olmayan Değer Yöntemi

\section{ABSTRACT}

This era's digital transformation has significantly increased the number and effectiveness of enterprises using information technologies (IT) to operate. The difference between an IT enterprise's book value and market value is explained as intellectual capital. The study aims to determine whether the intellectual capital is higher for the enterprises traded in the Borsa İstanbul (BIST) stock exchange's information sector and calculate the amount. Considering that the Industry 4.0 roadmap was devised in Turkey in 2018 and the awareness of enterprises regarding this issue has increased, the financial statement data of enterprises in 2018, 2019 and 2020 have been analyzed using the calculated intangible value method. Of the 18 enterprises, 3 did not meet the analysis requirements and were excluded, so the intellectual capital value was for 15 enterprises. When the results were compared with those of previous studies, the value of intellectual capital in the IT sector increased significantly. Thus, it was concluded that in this change, the increase in the contribution of intellectual capital in Industry 4.0 applications are effective.

Keywords: Industry 4.0, Intellectual Capital, Calculated Intangible Value Method

Başvuru/Submitted: 22.10.2021 Revizyon Talebi/Revision Requested: 15.12.2021 Son Revizyon/Last Revision Received: 23.12 .2021 Kabul/Accepted: 27.12 .2021 Sorumlu yazar/Corresponding author: İlknur Ergün / iergun@nku.edu.tr

Atıf/Citation: Ergun, I. ve Ozcan, I. (2022). Endüstri 4.0 döneminde entelektüel sermaye: bilişim sektörü üzerine bir araştırma. Muhasebe Enstitüsü Dergisi - Journal of Accounting Institute, 66, 79-94. https://doi.org/10.26650/MED.1013615 


\section{Extended Abstract}

In the develepoment that started with the Industrial Revolution, the growth of science and technology, globalization, the introduction of the internet into the mainstream, and digital transformation, Industry 4.0 applications have profoundly affected all areas of life. At present, when the world has become a global market, competition among enterprises has reached destructive dimensions. The prerequisite of competition and sustainability is the ability to effectively manage intellectual capital, accepted as the output of Industry 4.0 (Yıld1z and Genç, 2019: 39). In the traditional approach, the competitive advantage of enterprises is associated with the effective use of material resources; however, in the Industry 4.0 era, the focus is on the effective use of intellectual capital to increase enterprises' competitiveness (Ramanova et al.,2017: 141).

Although there is no general definition, Stewart (1997) defines intellectual capital as "the sum of everything the employees of the enterprise know and everything which gives a competitive advantage in the market", Brooking (1997) defines it as "the difference between the book value of an enterprise and the value that is ready to be paid to that enterprise in the market" (Yılmaz, Şahin ve Güler, 2005: 94).

The market value of the companies enjoying top ranks globally is significantly higher than their book value; this difference is due to intellectual capital. However, intellectual capital is excluded from the financial statements of enterprises although it is quite valuable which is a subject of criticism. One sectors where intellectual capital is the most intense is that of information technologies (IT). After digital transformation and Industry 4.0 applications; IT companies rank as some of the biggest enterprises in the world (Derdiyok, Doğru and Ünal, 2020: 17-18). For this reason, it is essential to calculate our country's intellectual capital made in the IT sector and determine its development over the years.

Although there is no accepted method for calculating intellectual capital, various methods have been employed to attempt it. These methods comprise two groups (Pazarçeviren and Kaya, 2018: 334):

a) Methods used to calculate intellectual capital at the business level

b) Methods used to calculate intellectual capital by dividing it into its components

"The Calculated Intangible Value" method, one of the measurement methods at the enterprise level, has more advantages than other methods. Since it is based on audited financial statement data and the results are more realistic and comparable than other methods, this method has been used in the application of this study (Stewart 1997; Pazarçeviren and Kaya, 2018).

The study aims to analyze intellectual capital, which has increased in importance during the Industry 4.0 period, through the financial statement data of the enterprises traded on the Borsa İstanbul (BIST) stock exchange's information sector. For this purpose, the intellectual capital of enterprises and the calculated intangible value method has been analyzed using the data of the end-of-period financial statements for 2018, 2019 and 2020. Of the 18 enterprises in the BIST IT sector, 3 were excluded from the evaluation because they remained below the industry average in terms of tangible asset earnings ratio. After calculating the weighted mean capital costs, the intellectual capital value was determined 15 for enterprises. While the results are comparable with previous studies, intellectual capital values in the IT sector have increased significantly. As such, this increase in the contribution of intellectual capital in Industry 4.0 applications was determined to be effective. 


\section{Giriş}

Endüstri Devrimi 18. yy’da gerçekleşmiş ve çalışma koşulları ile ekonomik ve sosyal sistemleri tümden değiştirmiştir. Endüstri 1.0 olarak da adlandırılan bu devrimden itibaren, Endüstri 4.0'a uzanan süreçte yaşanan değişim başlangıçta yavaş ilerlerken, günümüzde baş döndüren bir hızla devam etmektedir. Endüstri 1.0 döneminde simge haline gelen iplik makinesinin, Avrupa dışına yayılması nerede ise 120 yıl sürmüşken, Endüstri 4.0 dönemine geçişi hızlandıran internetin tüm dünyaya yayılması 10 yıldan kısa sürede gerçekleşmiştir (Altuk Özden, 2018: 1641).

2000'li yılların başlarında sermaye liberizasyonu gerçekleşmiş ve bunun sonucunda dünyada artan yıkıcı rekabet koşulları, yüksek yaşam standartlarının varlığı, bilgi yoğun hizmet sektörü ihtiyaçları nedeni ile insan sermayesi etkinliğinin geliştirilmesi zorunluluğu ortaya çıkmıştır. Entelektüel sermayeye yapılan yatırımlar ile işletmeler rekabet edilebilirliği arttırmayı, müşterilerine farklı ve katma değeri yüksek olan ürün ve hizmetler sunmayı amaçlamaktadırlar (Mavridis, 2004: 138; İşseveroğolu ve Ercan, 2019: 116).

Otomasyon sisteminden dijitalleşmeye geçtiğimiz günümüzde yapay zeka, robotlar, üç boyutlu yazıcılar, nesnelerin interneti, siber fiziksel sistemler, makinaların hatta insanların yerini alarak Endüstri 4.0 olarak ifade edilen sanayi devrimi gerçekleşmiş ve hayatın her alanını tümden değişime zorlamıştır. Endüstri 4.0, ilk defa Almanya'da 2011 yılında ifade edilmiş ve birçok ülke tarafından benimsenmiştir. Sınırların ortadan kalkarak dünyanın küresel bir pazar haline geldiği günümüzde, işletmelerin müşterileri ellerinde tutmaları zorlaşmış, işletmeler arası rekabet yıkıcı boyutlara ulaşmıştır. Rekabetin ön koşulu ise Endüstri 4.0’’n çıktısı kabul edilen somut varlıkları değil somut olmayan varlıkları etkin yönetebilme becerisi olmuştur (Yıldız ve Genç, 2019: 39). Bu rekabet ortamında işletmelerin ve ülkelerin varlıklarını sürdürebilmeleri, başarılı olabilmeleri için dünyadaki bu gelişmeleri yakından takip etmeleri bir zorunluluk haline gelmiştir.

Günümüzün toplumlarının, bilgi toplumlarına yönelişi ile birlikte entelektüel sermaye de dikkat çeken bir unsur haline gelmiştir. Ancak işletmeler için son derece önemli hale gelen entelektüel sermaye işletme varlıkları arasında raporlanamazken, işletme değeri ve entelektüel sermaye arasında ilişkiyi tespit etmek amacı ile pek çok çalışma yapılmıştır. Günümüzde değer yaratan, zenginliğin yeni kaynağı olan ve bilgi varlığg şeklinde isimlendirilen entelektüel varlıkların ölçümü bir zorunluluk haline gelmiştir (Aslanoğlu ve Zor, 2006: 152).

Ülkemizde 2017 yılından itibaren Bilim, Sanayi ve Ticaret Bakanlığı'nın duyuru ve çalışmaları sayesinde Endüstri 4.0 bilincinin ve farkındalığının arttığı düşünülmektedir (Yüksel ve Şener, 2017: 299; Kesbiç, 2020: 205). Endüstri 4.0 süreci ile ilgili yol haritasının, devlet eliyle 2018 yılı başlarında oluşturulması, işletmelerin bu konudaki farkındalığının artmasında önemli rol oynamıştır. Maddi olmayan varlıklar içerisinde yer alan ancak finansal tablolarda raporlanmayan entelektüel sermaye ise Endüstri 4.0’1 gerçekleştirmek için itici güç olmuştur. Bu perspektiften hareketle çalışma sorusu; “dünyada baş döndürücü bir hızla gelişen ve ülkemizde de etkileri görülen Endüstri 4.0 döneminde, bilişim sektöründe, finansal tablolarda raporlanmayan entelektüel sermaye varlığı değişim göstermiş midir?” şeklinde belirlenmiştir.

Çalışmada, BİST’te yer alan bilişim sektöründeki işletmelerin entelektüel sermayelerinin ölçülmesi ve önceki yıllarla karşılaştırılması amaçlanmaktadır. Teknoloji şirketleri, sürdürülebilir rekabet avantajını, proaktif, yenilikleri takip eden bir yapı içerisinde devam ettirebilmektedirler. Endüstri 4.0 döneminde ve özellikle bilişim sektöründe yoğun olarak yer alan entelektüel sermayenin ölçülmesi önem arz etmektedir.

Çalışmanın ikinci bölümünde entelektüel sermaye kavramı, Endüstri 4.0 ve entelektüel sermaye ilişkisi ile ölçme yöntemleri ele alınmıştır. Ardından entelektüel sermayenin ölçümü ile ilgili literatür çalışmasına yer verilmiştir. İnsan sermayesi, teknoloji sektöründe çok önemli bir yer tutmaktadır. Bu nedenle çalışmanın uygulama bölümünde, BİST’te işlem gören bilişim işletmeleri seçilerek, hesaplanmış maddi olmayan değer yöntemi ile değerlendirme yapılmıştır. Çalışmada, Endüstri 4.0 uygulamalarının etkilerini de tespit etmek amacıyla bu işletmelerin 2018-2020 arasındaki dönemlerine ait finansal tabloları analize konu edilmiş ve entelektüel sermayeleri hesaplanmıştır. Belirlenen döneme ait çalışma sonuçlarının önceki yıllarda gerçekleştirilen çalışmaların sonuçları ile karşılaştırılmasının ulusal literatüre katkı sağlayacağı düşünülmektedir. Çalışmanın son bölümünde ise sonuçlar değerlendirilmiştir. 


\section{Entelektüel Sermaye}

Sanayi toplumlarında, etkinlik ve verimliliği arttırdığg ve değer yaratma sürecinde önemli oldukları için işletmelerin maddi varlıkları, maddi olmayan varlıklarına göre daha önemli bulunmuştur. Günümüzde ise bilgi ve teknolojiye dayalı bir üretim süreci etkin olduğundan işletmelerin fiziksel olarak finansal tablolarında görülmeyen varlıkları son derece önemli hale gelmiştir. Bazı işletmelerin sahip olduğu fiziksel varlıklarının defter değeri ile piyasa değeri arasında dikkat çeken farklar olduğu görülmektedir. Entelektüel sermaye adı verilen ve işletmenin varlıkları arasında raporlanamayan bu değerler, işletmelerin kâr yaratma potansiyelini etkileyerek, piyasa değerlerini yükseltmektedir. Entelektüel sermayenin ölçülerek görünür hale gelmesi, finansal tablo kullanıcıları açısından işletme ile ilgili verecekleri kararlarda büyük önem taşımaktadır. Endüstri 4.0 döneminde entelektüel sermaye daha değerli hale gelmiştir.

\subsection{Entelektüel Sermaye Kavramı}

Bilgi toplumuna geçişle birlikte, işletmelerin piyasa değerinde görünmeyen bazı değerlerin de yer aldığı ve bunların entelektüel sermaye olarak ifade edildiği görülmektedir (Yılmaz ve ark., 2005: 94). Ancak entelektüel sermaye için genel kabul görmüş bir tanım vermek mümkün değildir. Bu kavram ilk defa John Kenneth Galbrath tarafından 1969 yılında kullanılmıştır (Barut, Karabayır ve Torusdağ, 2019: 170). Stewart (1997), entelektüel sermayeyi “işletmeye piyasada rekabet üstünlüğü kazandıran, işletme iç paydaşlarının bildiği her şeyin toplamı” şeklinde tanımlarken, Brooking (1997), “bir işletmenin defter değeri ile piyasada o işletme için ödenmeye hazır olan değer arasında oluşan farktır” şeklinde tanımlamıştır (Yılmaz, Şahin ve Güler, 2005: 94).

Sullivan’a göre, kâra dönüşebilen bilgi entelektüel sermaye olarak ifade edilmektedir. Kâra dönüşen bilgi ise beşerî ve entelektüel sermayeyi içermektedir. İşletme çalışanlarının yetenek, yatkınlık, bilgi birikimi ve teknik bilgileri insan sermayesini oluşturmaktadır. Çalışanlar, işletme hiyerarşisi içerisinde sahip oldukları bu potansiyeli verimli olarak kullanabilecekleri pozisyonlarda bulunmalıdırlar. İşletme tarafından beşerî sermayenin bu potansiyeli korunup, işletme kültürü içerisine yerleştirildiği zaman entelektüel sermaye yaratılmaktadır. Bu sağlandığı zaman işletmeler ihtiyaç duydukları bilgi ve yetenek için o bilgiye sahip kişiler yerine işletme içerisinde var olan entelektüel sermayeyi kullanabilirler (Garavan, Morley, Gunnigle ve Collins, 2001: 50).

Uluslararası Muhasebe Standartları Komitesi (IASC) ise maddi olmayan varlıkları entelektüel sermaye olarak ifade etmiş ve üretim hakları, ticari marka, patent, telif hakları, lisanslar, formüller ve bilgisayar yazılımları gibi soyut kavramların bütünü olarak tanımlanmıştır (Ulf, 1997; Koç ve Avcı, 2020: 378). Ancak entelektüel sermaye, bileşenlerinin değerinin makul bir biçimde ölçülememesi, kontrol edilememesi ve diğer varlıklardan ayrılamaması nedeni ile Uluslararası Finansal Raporlama Standartları gereğince muhasebeleştirilme kriterlerini sağlamadığından aktifleştirilememektedir (İşseveroğlu ve Ercan, 2019: 113).

Entelektüel sermayenin genel bir tanımı olmasa da yapılan literatür incelemesinde kavramın genel olarak üç unsuru içerdiği görülmektedir. Bunlar; insan ve müşteri sermayesi ile yapısal sermaye ve müşteri sermayesi olarak belirtilmektedir.

Insan Sermayesi: Çalışanların kendilerine verilen görev ve sorumlulukları yerine getirirken, sahip oldukları, yaratıcılık, bilgi ve yeteneklerinin bütünüdür. Kişinin doğal yeteneği, eğitimi ve tecrübeleri sonucunda kendisinin sahip olduğu bir değer olduğundan işletme bunu sahiplenemez (Çetin, 2005: 361-362).

Yapısal Sermaye: İşletmenin iskeleti olup, onun ayakta durmasını sağlamaktadır. Kısaca çalışanların eve döndükleri zaman yanlarında götüremeyip, işletmede bıraktıklarının tümü olarak ifade edilmektedir. Yapısal sermayenin, yönetim felsefesi, örgüt kültürü, yönetim süreçleri, bilgi teknolojisi sistemi, örgütsel ilişki ağları ile finansal ilişkiler şeklinde sıralanan altı unsuru vardır. Yapısal sermayenin en önemli görevi örgüte, sahip olunan insan sermayesinden maksimum fayda sağlayacak işlerliği kazandırmaktır (Eren ve Akpınar, 2004:10).

Müşteri Sermayesi: İşletmelerin, müşterileri, tedarikçileri ve toplumun geri kalan kesimi ile ilişkisinin değeri olup, onların işletmeye olan bağlılıklarını ifade etmektedir. Entelektüel sermaye unsurları içerisinde değeri en belirgin unsurdur. 
Günümüzde işletmeler, kârlarını arttırabilmek için müşterileri memnun etme çabası içerisindedirler (Yörük ve Erdem, 2008: 399-400).

\subsection{Endüstri 4.0 Döneminde Entelektüel Sermaye}

Küreselleşmenin egemen olduğu günümüzde, bilginin gücü ile işletmelerin rekabet gücü değişmiş, sürdürülebilirliği sağlamanın ve başarının en önemli unsuru bilgi haline gelmiştir. Geleneksel işletmelerde, daha fazla üretip, daha çok kâr etmek amaçlanırken, modern işletmelerde müşteri taleplerini karşılayabilmek için daha çok bilgiye sahip olmak temel amaç haline gelmiştir (Yıldız ve Genç, 2020: 15). Geleneksel yaklaşımda işletmelerin rekabet avantajı maddi kaynakları etkin kullanma ile ilişkilendirilirken, Endüstri 4.0 döneminde işletmelerin rekabet gücünü arttırmak için entelektüel sermayeyi etkin kullanmak üzerine odaklanılmaktadır (Romanova, Berg ve Matveeva, 2017: 141).

Entelektüel sermaye, uzmanlık bilgisi, teknoloji ve ilişki ağlarını içeren maddi olmayan varlıklara büyük önem vermiştir. Entelektüel sermaye, kurumsal performansın ve değer yaratmanın ana kaynağı ve itici gücü olarak tanımlanmıştır. Dördüncü sanayi devrimi öncelikle yeni bir bilgi ve sosyal ă̆ modeli gerektirmektedir. Bu durumda, yeni çevre ve yaşanan değişimlere adapte olmak için bilgi inovasyonu çok ihtiyaç duyulan bir hale gelmiştir. Maddi olmayan varlıklar içerisinde yer alan entelektüel sermaye bazlı yaklaşım, Endüstri 4.0’’ gerçekleştirmek için organizasyonlara yardımcı olmaktadır (Cabrita, Cruz-Machado ve Duarte, 2019: 2).

İşletmelerin üretim için gerekli kaynaklara sahip olması rekabet üstünlüğü sağlaması için yeterli olmayıp bunları etkin bir şekilde kullanabilme yeteneğinin olması da önemlidir. Bu yeteneklerin diğer işletmelerden farklı olup, değerli olması, nadir olması, ikamesinin olmaması ve taklit edilememesi son derece önemlidir. Bu özellikler işletmelere rekabet avantajı sağlayan özellikler olup entelektüel sermayenin kullanım becerisi olarak da adlandırılmaktadır. Günümüzde bir işletmenin entelektüel becerisi ne kadar güçlü ise yenilik yapabilme yeteneği de o denli güçlü olmaktadır (Yıldız ve Genç, 2019: 41). Dördüncü Sanayi Devrimi döneminde entelektüel sermaye, işletmelerin rekabet gücü açısından en önemli faktör olmuştur. Geleneksel üretimde rekabet avantajı sağlayan maddi kaynakların yerini entelektüel sermaye almıştır (Kesbiç, 2020: 187).

Endüstri 4.0 ile yaşanan dijital dönüşüm, işletmelerin düşük değerli varlık yapısı ile çok yüksek piyasa değerine ulaşmasına olanak vermiştir. Ağustos 2020 verilerine göre dünyanın en büyük teknoloji şirketlerinden Apple şirketinin piyasa değerinin defter değerine oranı (PD/DD) 25.6 olup, piyasa değeri 1.850 milyar dolardır. Amazon şirketi 1.510 milyar dolar piyasa değeri ile dünya genelinde en büyük şirketler arasında önde gelmektedir. Şirketin PD/DD oran1 20.5 olup hisselerinin fiyat kazanç (F/K) oran1 116.1'dir. Bu şirketlerin defter değeri ve piyasa değeri arasında oluşan önemli fark entelektüel sermayenin değeri ile açıklanmaktadır. Financial Times Global 500 listesinde en yüksek piyasa değerine sahip ilk 7 şirketin teknoloji şirketi olması, bu sektörde entelektüel sermayenin önemini ortaya koymaktadır (Derdiyok, Doğru ve Ünal, 2020: 17-18).

\subsection{Entelektüel Sermayenin Ölçülmesi}

Fiziksel varlığı olmayan entelektüel sermayenin ölçülüp, finansal tablolarda maddi olmayan duran varlıkların içerisinde raporlanması için Türkiye Muhasebe Standartları 38'de belirtilen maddi olmayan duran varlık tanımının şartlarını sağlaması gerekmektedir. Standart uyarınca maddi olmayan duran varlığın muhasebeleştirilmesi için; söz konusu varlığın şerefiyeden ayrı belirlenebilmesi, geçmişte gerçekleşmiş birtakım olayların sonucu olarak işletme tarafından kontrol edilebilmesi, gelecekte işletmeye ekonomik yarar sağlaması, beklenen bu ekonomik faydanın muhtemel olması ve varlığın maliyetinin güvenilir bir biçimde ölçülebiliyor olması gerekmektedir (TMS 38, prg: 9-18). Entelektüel sermaye aşağıdaki nedenlerle maddi olmayan duran varlık olarak tanımlanamaz ve muhasebeleştirilemez;

a) "Belirlenebilirlik, kontrol ve gelecekteki ekonomik yararın varlığı” şartlarını sağlamadığı için maddi olmayan varlık tanımına girmemektedir,

b) Genel kabul görmüş bir ölçüm yöntemi ile maliyeti güvenilir biçimde ölçülemediğinden muhasebeleştirme kriterlerini sağlamamaktadır. 
Ünlü yönetim bilimci Drucker’ın “ölçemediğinizi yönetemezsiniz” yönetim anlayışına göre işletmeler için çok değerli bir unsur olan entelektüel sermayenin ölçülmesi son derece önem arz etmektedir. Entelektüel sermayeyi ölçmenin işletmeye sağlayacağı birçok fayda bulunmaktadır. Bunların başlıcaları; yöneticiler açısından işletmede değer yaratan unsurların anlaşılması, işletme performansının değerlemesinde güvenilir bir değerleme aracı elde edilmesi ve finansal kaynak sağlarken, işletmelerin ödeme güçlerinin güvenilir bir biçimde tespit edilmesidir (Yörük ve Erdem, 2008: 400).

İşletmenin sahip olduğu entelektüel sermayenin önemi gittikçe artıyor olmasına rağmen, literatürde evrensel olarak genel kabul görmüş bir entelektüel sermaye ölçüm yöntemi bulunmamaktadır. Ancak işletmelerin gerçek değerini yansıtması açısından da son derece önemli olması nedeni ile entelektüel sermayeyi ölçmek için çeşitli yöntemler geliştirilmiştir. Bu yöntemler iki grupta toplanmaktadır (Pazarçeviren ve Kaya, 2018: 334);

A- Entelektüel sermayenin işletme düzeyinde ölçülmesinde kullanılan yöntemler

\section{$\checkmark$ Piyasa Değeri ve Defter Değeri Oranı}

$\checkmark$ Piyasa Değeri ile Defter Değeri Arasındaki Fark

$\checkmark$ Tobin'in Q Oranı

$\checkmark$ Hesaplanmış Maddi Olmayan Değer

B- Entelektüel sermayenin bileşenlerine ayrılarak ölçülmesinde kullanılan yöntemler

$\checkmark$ Dengelenmiş Skor Kartı

$\checkmark$ Skandia Pusulası

$\checkmark$ Maddi Olmayan Varlıklar Cetveli

$\checkmark$ Entelektüel Sermaye Endeksi

$\checkmark$ Teknoloji Brokeri

$\checkmark$ Entelektüel Katma Değer Katsayısı

Çalışmada, işletmelerin finansal tabloları dikkate alınarak, entelektüel sermayenin işletme düzeyinde ölçüldüğü yöntemlerden "hesaplanmış maddi olmayan değer yöntemi” kullanılmıştır. Bu nedenle entelektüel sermayenin bileşenlerine ayrılarak ölçülmesine ilişkin yöntemlere değinilmemiştir. Entelektüel sermayenin işletme düzeyinde ölçülmesinde kullanılan yöntemlerde yer alan hesaplamalar ve yöntemlerin birbirlerine göre üstün ve zayıf yönleri Tablo 1'de sunulmaktadir.

\begin{tabular}{|c|c|c|c|c|}
\hline Yöntemler & $\begin{array}{c}\text { Piyasa Değeri ve Defter } \\
\text { Değeri Oranı }\end{array}$ & $\begin{array}{l}\text { Piyasa Değeri } \\
\text { ile Defter Değeri } \\
\text { Arasındaki Fark }\end{array}$ & Tobin'in Q Oranı & Hesaplanmış Maddi Olmayan Değer \\
\hline Hesaplama & $\begin{array}{c}\text { Piyasa Değeri / Defter } \\
\text { Değeri }\end{array}$ & $\begin{array}{l}\text { Piyasa Değeri } \\
\text {-Defter Değeri }\end{array}$ & $\begin{array}{l}Q=\text { Piyasa Değeri/ } \\
\text { Varlıkların Yerine } \\
\text { Koyma Maliyeti }\end{array}$ & $\begin{array}{c}7 \text { aşamada gerçekleştirilir. } \\
\text { 1; üç yıl için ortalama vergiden önceki kâr } \\
\text { (VÖK) hesaplanır. } \\
\text { 2; üç y1l için ortalama maddi varlık hesaplanır. } \\
\text { 3; işletmelerin maddi varlık karlılığı hesaplanır. } \\
\text { 4; sektörün maddi varlık karlılı̆̆ı hesaplanır. } \\
\text { 5; işletmelerin brüt ek kazançları hesaplanır. } \\
\text { 6; işletmelerin net ek kazançları hesaplanır. } \\
\text { 7; işletmelerin entelektüel sermayeleri hesaplanır }\end{array}$ \\
\hline
\end{tabular}




\begin{tabular}{|c|c|c|c|}
\hline Üstün yönleri & $\begin{array}{c}\text {-Hesaplamada kullanılan verilerin kolay elde } \\
\text { edilebilir olması } \\
\text {-Hesaplanmasının basit olması }\end{array}$ & $\begin{array}{c}\text { Hesaplanmasinın } \\
\text { basit olmas1 }\end{array}$ & $\begin{array}{c}\text {-Denetlenmiş finansal tablo verilerine dayanması } \\
\text {-Hesaplamada kullanılan verilerin kolay elde } \\
\text { edilebilir olması } \\
\text {-Daha gerçekçi ve karş1laştırılabilir sonuçlar } \\
\text { vermesi }\end{array}$ \\
\hline Zayıf yönleri & $\begin{array}{c}\text {-İşletmenin piyasa değerini etkileyen faktörlerin } \\
\text { çok çeşitli olması } \\
\text {-Seçilen muhasebe politikalarının defter } \\
\text { değerini etkilemesi } \\
\text { - Sadece hisse senetleri borsada işlem gören } \\
\text { işletmelere uygulanabilmesi }\end{array}$ & $\begin{array}{l}\text { İşletmenin piyasa } \\
\text { değerini etkileyen } \\
\text { faktörlerin çok } \\
\text { çeşitli olması }\end{array}$ & Karmaşık ve zaman alıcı olması \\
\hline
\end{tabular}

Tablo 1'de sunulduğu üzere entelektüel sermayeyi işletme düzeyinde ölçen yöntemlerden hesaplanmış maddi olmayan değer yönteminin karmaşık ve zaman alıcı bir yöntem olmasına rağmen diğer yöntemlerle kıyaslandığında üstün yönleri daha fazladır. Denetlenmiş finansal tablo verilerine dayanması ve sonuçların diğer yöntemlere göre daha gerçekçi ve karşılaştırılabilir olması nedeni ile çalışmanın uygulamasında bu yöntem kullanılmıştır.

\section{Literatür}

Entelektüel sermayenin önemi anlaşılıp, finansal tablolarda yer almamasının sakıncaları anlaşılınca, entelektüel sermayenin ölçülmesi ve fïma değeri üzerine etkileri konusunda çalışmalar yapılmaya başlanmıştır. Çalışmalarda farklı ölçüm yöntemleri kullanılırken, entelektüel sermayeyi işletme düzeyinde ölçen yöntemlerin ve özellikle "Hesaplanmış Maddi Olmayan Değer" yönteminin tercih edildiği söylenebilir (Pazarçeviren ve Kaya, 2018: 336). Adı geçen yöntem ilk kez Stewart tarafından 1997 yılında açıklanmıştır. Yöntemin işleyişi yedi aşamada anlatılmıştır (Stewart, 1997: 254-255).

Uzay ve Savaş (2003), mobilya sektöründe faaliyet gösteren ve İSO 500'de yer alan şirketlerin 1999 ve 2001 yıllarına ait finansal tabloları üzerinde çalışma yapmışlardır. Çalışmada “Hesaplanmış Maddi Olmayan Değer” yöntemi kullanılmış ve uygulama kapsamındaki şirketlerin entelektüel sermaye değerleri hesaplanmıştır. Bulunan değer ile şirketlerin defter değerleri ve net aktif toplamları arasındaki ilişki incelenmiş ve oransal olarak ifade edilmiştir. Sonuçta şirketlerin entelektüel sermaye açısından güçlendirilmeleri gerektiği ifade edilmiştir.

Kujansivu ve Lonnqvist (2007), Finlandiya Borsa'sında yer alan ve 11 endüstri kolunda faaliyet gösteren orta ve büyük ölçekli işletmelerin entelektüel sermaye değerini ve entelektüel sermayenin verimliliğini tespit etmek amacıyla 2001-2003 dönemini kapsayan bir araştırma yapmışlardır. Şirketlerin entelektüel sermaye değerini, Hesaplanmış Maddi Olmayan Değer (CIV) Yöntemi ile verimliliğini ise Entelektüel Katma Değer Katsayısı Yöntemi ile tespit etmişlerdir. Araştırmanın sonucunda CIV yöntemini uygulayarak, ortalama bir şirketin entelektüel sermaye değerinin 3.620.900 Euro olarak hesaplandığını, bunun da şirketlerin maddi duran varlıklarının defter değerinin yarısı kadar olduğunu ve entelektüel sermayenin elektronik sektöründe en yüksek olarak ölçüldüğünü açıklamışlardır. Ayrıca yaptıkları korelasyon analizi sonucunda, şirketlerin entelektüel sermayesinin değeri ve verimlilik arasında yakın bir ilişki olduğunu açıklamışlardır. Volkov ve Garanina (2007) ise 2001-2005 Rusya Borsası verilerine dayanarak seçtikleri şirketler üzerinde yaptıkları çalışmada, günümüzün bilgi tabanlı ekonomisinde, maddi olmayan varlıkların önemini ortaya koymayı amaçlamışlardır. Seçilen 43 Rus şirketin finansal tabloları üzerinde Hesaplanmış Maddi Olmayan Değer Yöntemini uygulayarak, maddi olmayan varlık değerlerini hesaplamış, piyasa değeri üzerindeki etkisini ölçmüşlerdir. Çalışmanın sonucunda, Rus ekonomisinde maddi varlık yatırımlarının maddi olmayan varlıklara kıyasla çok daha kârlı olduğu tespit edilirken, geliştirilen modellerle varlıkların piyasa değeri ile hem maddi hem de maddi olmayan varlıkların temel değeri arasında anlamlı ilişkiler bulunmuştur.

Sundac ve Krmpotic (2009), işletmelerde değer yaratmak için kullanılacak bilgiyi temsil eden entelektüel sermayenin ölçümü için yeni yöntemler kullanılması gerektiğini savunan bir çalışma gerçekleştirmiştir. Çalışmada, Hırvatistan’da farklı sektörlerde faaliyet gösteren 4 büyük işletme üzerinde Hesaplanmış Maddi Olmayan Değer Yöntemi uygulanmış ve maddi varlık getiri oranı daha yüksek olan işletmelerin diğerlerine oranla daha başarılı olduğu belirtilmiştir. Bu durumun maddi varlık yönetiminin başarısından kaynaklandığı vurgulanmıştır. Çalışmada uygulanan finansal oran analizlerinin 
sonuçları ile Hesaplanmış Maddi Olmayan Değer Yöntemi sonuçlarının paralellik göstermesi nedeni ile bu iki yöntemin tamamlayıcı olduğu vurgulanmıştır.

Zor ve Cengiz (2013), BİST’te yer alan enerji şirketlerinin üç yıllık finansal tablolarından faydalanarak, entelektüel sermayelerini ölçmüşlerdir. Çalışmada Piyasa Değeri (PD) / Defter Değeri (DD) Oranı ve Hesaplanmış Maddi Olmayan Değer Yöntemi kullanılarak sonuçları karşılaştırılmıştır. Çalışmanın sonucunda enerji şirketlerinin son üç yıllık ortalama PD / DD oranlarının 1,74 olduğu, 1990 yıllardan sonra Dow Jones Endeksinde oluşan ortalama PD/DD oranının ise 2 ile 5 arasında kademeli arttığı belirtilmektedir. Bu nedenle ülkemizdeki enerji piyasalarında entelektüel sermaye değerinin henüz tam anlamıyla fark edilmediği ve entelektüel sermayenin geliştirilmesine yönelik çabaların yetersiz olduğu sonucuna varılmıştır.

Bölükbaşı (2014) tarafından hesaplanmış maddi olmayan değer yöntemini kullanarak, BİST’e kayıtlı sigorta şirketlerinin entelektüel sermaye değerini ölçmek amacıyla yapılan çalışmada bazı sigorta şirketlerinin sektör ortalamasının altında maddi varlıklara sahip olmalarına rağmen yüksek bir entelektüel sermaye değerine ulaştıkları tespit edilmiştir. Ancak sektör ortalamasının çok üstünde maddi varlığa sahip olan bazı şirketlerin ise entelektüel sermaye değerlerinin nispeten daha düşük olduğu görülmüştür. Pazarçeviren ve Kaya (2018) tarafından yapılan benzer bir çalışmada BİST’te Dokuma, Giyim Eşyası ve Deri Sektörü’nde faaliyet gösteren şirketlerin 2014, 2015 ve 2016 yıllarına ait entelektüel sermaye değerlerini tespit etmek amaçlanmıştır. 10 şirketin entelektüel sermayeleri hesaplanırken diğerlerinin entelektüel sermayelerini etkin kullanamamaları nedeniyle hesaplama yapılamamıştır.

Mondal (2016), işletmelerin entelektüel sermaye performansı ile entelektüel sermaye değerleri arasındaki ilişkiyi ölçtüğü çalışmasında Hindistan'da faaliyet gösteren 50 adet yazılım ve ilaç şirketi üzerinde bir analiz gerçekleştirmiştir. Entelektüel sermaye performansının ölçümü için entelektüel katma değer katsayısı yöntemi ve Hesaplanmış Maddi Olmayan Değer Yöntemi uygulanmıştır. Ampirik bulgular, işletmelerin entelektüel sermayelerinin etkin yönetiminin entelektüel sermaye performansının değerini artırabileceğini göstermiştir.

Uyrun ve Bilici (2020) ise BİST’e kayıtlı 12 adet turizm şirketinin üç yıllık finansal tablolarında aynı yöntemi kullanarak yaptıkları çalışmada sadece 5 şirketin entelektüel sermaye değerini ölçmüşlerdir. Diğer şirketler hesaplamadaki bazı kısıtlamalar dolayısı ile analiz dışında bırakılmıştır. Çalışma sonucunda VÖK oranları yüksek, ancak maddi varlıkları kısmen düşük olan işletmelerin entelektüel sermayelerinin yüksek çıktığı belirlenmiştir.

Akyüz (2021), BİST bünyesinde işlem gören orman ürünleri sanayi sektörünü incelenmiştir. Hesaplanmış maddi olmayan değer yöntemi kullanılarak yapılan çalışmada 2017-2018-2019 yılları değerlendirilmeye alınmış ve çalışma sonucunda kâğıt ve kâğıt ürünleri sanayi sektöründe 3, orman ürünleri ve mobilya sanayi sektöründe 2 işletmenin entelektüel sermaye konusunda başarılı bir konumda oldukları belirlenmiştir.

Ülkemizde, entelektüel sermayenin yoğun olduğu sektörlerden teknoloji sektöründe çeşitli çalışmalar yapılmıştır. Kayalı, Yereli ve Ada (2007), “Entelektüel Katma Değer Katsayısı Yöntemi” ile İMKB’de işlem gören teknoloji şirketlerinin firma değerini belirlemeye yönelik yaptıkları çalışmalarında, ülkemizdeki teknoloji şirketlerinin çalışmanın yapıldığı dönemde henüz entelektüel sermayenin önemini kavrayamadıkları ve bu nedenle firma değerlerinim olduğundan daha düşük belirlendiğini tespit etmişlerdir. Kendirli ve Konak (2015), BİST’te faaliyetlerini sürdüren 12 bilişim şirketinin 2008 ve 2012 yıllarını kapsayan 5 yıllık piyasa ve muhasebe verileri ile Entelektüel Katma Değer Katsayısı Yöntemini dikkate alan bir çalışma gerçekleştirmişlerdir. Şirket performansı ve verimlilik değişkenleri ile analizde kullanılan sermaye entelektüel sermaye unsurlarından insan sermayesi arasında istatiksel açıdan anlamlı ve pozitif ilişki tespit etmişlerdir. Kuğu (2016) ise BİST’te yer alan teknoloji sektöründeki 14 bilişim şirketinin, 2013,2014,2015 yıllarına ait finansal verileri ile Hesaplanmış Maddi Olmayan Değer Yöntemini kullanarak entelektüel sermayelerini ölçmüştür. Çalışmanın sonucunda 14 şirketin sadece 3 tanesinde entelektüel sermaye oluştuğu, 9 şirketin ortalamanın altında maddi duran varlık kârlılığı elde ettiği ve 2 şirketin ise dönemler itibarı ile zarar ettiği tespit edilmiştir. Araştırmaya konu olan şirketlerin bazılarının sadece üretim, bazılarının ticaret ve diğerlerinin sadece yazılım konuları üzerine faaliyet göstermesinden dolayı maddi duran varlıkları ile 
maddi olmayan duran varlıklarında büyük farklılıklar olmasının sonuçlar üzerinde etkili olduğu belirtilmiştir. İşseveroğlu ve Ercan (2019) da entelektüel katma değer katsayısı yöntemi ile BİST’te faaliyet gösteren 15 bilişim şirketinin 2008-2017 yılarını kapsayan 10 yıllık mali tabloları ile entelektüel sermaye unsurlarının kârlılık ve verimlilik üzerindeki etkilerini incelemişlerdir. Çalışmanın sonucunda kârlılık üzerinde önemli etki tespit edilirken verimlilik üzerindeki etkinin düşük olduğu tespit edilmiştir.

\section{Metodoloji}

Çalışmanın bu bölümünde araştırmanın amacı, kapsamı, yöntemi ve elde edilen bulgular açıklanmıştır.

\subsection{Araştırmanın Amacı, Kapsamı ve Yöntemi}

Bu çalışma ile BİST’e kayıtlı ve bilişim sektöründe faaliyet gösteren işletmelerin 2018, 2019 ve 2020 yılları dönem sonu finansal tablolarındaki bilgiler kullanılarak entelektüel sermayelerinin ölçülmesi amaçlanmıştır. Çalışma BİST’te işlem gören ve teknoloji sektöründe faaliyet gösteren bilişim işletmelerini kapsamaktadır.

Analiz için veriler, Kamuyu Aydınlatma Plaftormu'nda yayımlanan dönem sonu bağımsız denetim raporlarından elde edilmiştir. Entelektüel sermaye ölçümünde sıklıkla kullanılan ve işletme düzeyinde ölçüm yapan hesaplanmış maddi olmayan değer yöntemi kullanılmıştır.

\subsection{Bulgular}

Çalışmada analize dâhil edilen işletmelerin 2018, 2019 ve 2020 yıllarına ait dönem sonu finansal tabloları incelenmiştir. 7 aşamada gerçekleştirilen "Hesaplanmış Maddi Olmayan Değer Yönteminin” aşamaları tablolar yardımı ile sunulmuştur. İlk aşamada öncelikle analize dâhil edilen dönemlerde tespit edilen vergiden önceki kâr (VÖK) ve maddi varlıklarının ortalamaları hesaplanmıştır. Ardından VÖK ortalamaları ile maddi varlık ortalamaları oranlanarak maddi varlık kazanç oranı tespit edilmiştir. Tablo 2'de, BİST'e kayıtlı ve çalışma kapsamında yer alan bilişim işletmelerinin isimleri, BİST kısaltmaları ile şirketlerin, kullanılan yöntem gereğince hesaplanan üç yıllık VÖK ortalamaları, maddi varlık ortalamaları ve maddi varlık kazanç oranları yer almaktadır.

Tablo 2: 2018-2020 Yıllarına Ait VÖK Ortalamaları, Maddi Varlık Ortalamaları ve Maddi Varlık Kazanç Oranları

\begin{tabular}{|l|c|c|c|c|}
\hline Tablo 2: 2018-2020 Yıllarına Ait VÖK Ortalamaları, Maddi Varlık Ortalamaları ve Maddi Varlık Kazanç Oranları \\
\hline & $\begin{array}{c}\text { BIST } \\
\text { KIsaltması }\end{array}$ & $\begin{array}{c}\text { VöK } \\
\text { Ortalaması } \\
\text { (a) }\end{array}$ & $\begin{array}{c}\text { Maddi Varlık } \\
\text { Ortalaması } \\
\text { (b) }\end{array}$ & $\begin{array}{c}\text { Maddi Varlık } \\
\text { Kazanç Oranı } \\
\text { (a / b) }\end{array}$ \\
\hline Arena Bilgisayar Sanayi ve Ticaret A.Ş. & ARENA & 48.276 .437 & 5.432 .927 & 8,886 \\
\hline Plastikkart Akıllı Kart İletişim Sistemleri Sanayi ve Ticaret A.Ş. & PKART & 9.018 .383 & 20.398 .319 & 0,442 \\
\hline Datagate Bilgisayar Malzemeleri Ticaret A.Ş. & DGATE & 34.398 .279 & 342.889 & 100,319 \\
\hline Fonet Bilgi Teknolojileri A.Ş. & FONET & 18.651 .174 & 6.696 .556 & 2,785 \\
\hline Logo Yazılım Sanayi ve Ticaret A.Ş. & LOGO & 92.663 .596 & 30.052 .136 & 3,083 \\
\hline Smartiks Yazılım A.Ş. & SMART & 5.635 .083 & 769.909 & 7,319 \\
\hline $\begin{array}{l}\text { Link Bilgisayar Sistemleri Yazılımı ve Donanımı } \\
\text { Sanayi ve Ticaret A.Ş. }\end{array}$ & LINK & 10.517 .006 & 346.608 & 30,343 \\
\hline Despec Bilgisayar Pazarlama ve Ticaret A.Ş. & DESPC & 22.987 .302 & 240.678 & 95,511 \\
\hline Armada Bilgisayar Sistemleri Sanayi ve Ticaret A.Ş. & ARMDA & 27.035 .578 & 9.745 .479 & 2,774 \\
\hline ARD Grup Bilişim Teknolojileri A.Ş. & ARDYZ & 38.375 .358 & 5.900 .362 & 6,504 \\
\hline $\begin{array}{l}\text { Papilon Savunma-Güvenlik Sistemleri Bilişim Mühendislik } \\
\text { Hizmetleri İthalat İhracat Sanayi ve Ticaret A.Ş. }\end{array}$ & PAPIL & 17.335 .352 & 833.659 & 20,794 \\
\hline Escort Teknoloji Yatırım A.Ş. & ESCOM & 2.840 .963 & 79.236 & 35,854 \\
\hline Kafein Yazılım Hizmetleri Ticaret A.Ş. & KFEIN & 25.534 .429 & 4.433 .503 & 5,759 \\
\hline Kron Telekomünikasyon Hizmetleri A.Ş. & KRONT & 8.379 .430 & 5.070 .789 & 1,652 \\
\hline Netaş Telekomünikasyon A.Ş. & NETAS & -118.801 .056 & 114.818 .284 & $-1,035$ \\
\hline Alcatel Lucent Teletaş Telekomünikasyon A.Ş. & ALCTL & 31.515 .425 & 6.952 .650 & 4,533 \\
\hline İndeks Bilgisayar Sistemleri Mühendislik Sanayi ve Ticaret A.Ş. & INDES & 181.020 .398 & 40.095 .207 & 4,515 \\
\hline Karel Elektronik Sanayi ve Ticaret A.Ş. & KAREL & 115.927 .928 & 111.622 .378 & 1,039 \\
\hline SEKTÖR ORTALAMASI & & 31.739 .504 & 20.212 .865 & \\
\hline
\end{tabular}


Tablo 2'de yer aldığı üzere en yüksek VÖK ortalamasına sahip işletmeler sırasıyla INDES, KAREL ve LOGO'dur. NETAS'ın VÖK ortalaması negatif hesaplanmıştır. En yüksek maddi varlık ortalamasına sahip işletme NETAS ve en düşük maddi varlık ortalamasına sahip işletme ise ESCOM'dur. VÖK ortalaması ile maddi varlık ortalamasının oranlanması ile hesaplanan maddi varlık kazanç oranı yalnızca NETAS için negatif bulunmuştur. En yüksek maddi varlık kazanç oranına sahip işletme ise DGATE'dir. Tablo 2'de ayrıca sektöre ait ortalamalar da yer almaktadır. Buna göre sektörün VÖK ortalaması 31.739.504TL olup maddi varlık ortalaması ise 20.212.865TL'dir. Sektörün ortalama maddi varlık kazanç oranı aşağıdaki şekilde hesaplanmıştır:

Sektör Maddi Varlık Kazanç Oranı= Sektörün VÖK Ortalaması/ Sektörün Maddi Varlık Ortalaması

$\mathbf{1 , 5 7}=31.739 .504 \mathrm{TL} / 20.212 .865 \mathrm{TL}$

Sektörün maddi varlık kazanç oranı 1,57 olarak hesaplandığından, Tablo 2'de sunulduğu üzere PKART, NETAS ve KAREL sektör ortalamasının altında kalmıştır. Yöntem gereğince ilgili işletmeler sonraki aşamalarda değerlendirmeye alınmamıştır. Analizin bir sonraki aşamasında sektörün maddi varlık kazanç oranı ortalamasının üzerinde olan işletmeler için brüt ve net ek kazanç tutarları hesaplanabilmesi için öncelikle şirketlerin kazanç tutarı hesaplanmıştır.

Şirketlerin Kazanç Tutarı= İşletmelerin Maddi Varlık Ortalaması * Sektörün Maddi Varlık Ortalaması

Şirketlerin kazanç tutarının hesaplanmasının ardından VÖK ortalamaları ile kazanç tutarları arasındaki farkı gösteren brüt ek kazanç tutarları bulunmuştur. 2018, 2019 ve 2020 yılları için tüm işletmelerde \%22 olarak kabul edilen vergi oranı dikkate alınarak vergi tutarları hesaplanmış ve brüt ek kazanç tutarlarından vergi tutarı çıkarılarak net ek kazanç tutarları bulunmuştur. İşletmelerin hesaplanan kazanç tutarları, brüt ek kazanç tutarları ve net ek kazanç tutarları Tablo 3’te sunulmuştur.

\begin{tabular}{|l|c|c|c|c|c|c|c|}
\hline Tablo 3: Brüt ve Net Ek Kazanç Tutarları & $\begin{array}{c}\text { Maddi } \\
\text { Varlık } \\
\text { Ortalaması } \\
\mathbf{( a )}\end{array}$ & $\begin{array}{c}\text { Sektörün } \\
\text { Maddi Varlık } \\
\text { Kârlılı Oranı } \\
(\mathbf{b})\end{array}$ & $\begin{array}{c}\text { Kazanç } \\
\text { Tutarı } \\
(\mathbf{a}) *(\mathbf{b})\end{array}$ & $\begin{array}{c}\text { VöK } \\
\text { Ortalaması } \\
(\mathbf{c})\end{array}$ & $\begin{array}{c}\text { Brüt Ek Kazanç } \\
\text { Tutarı } \\
(\mathbf{c})-(\mathbf{a}) *(\mathbf{b})\end{array}$ & $\begin{array}{c}\text { Vergi Tutarı } \\
(\mathbf{e})=(\mathbf{d}) * \mathbf{0 , 2 2}\end{array}$ & $\begin{array}{c}\text { Net Ek } \\
\text { Kazanç Tutarı } \\
(\mathbf{d})-(\mathbf{e})\end{array}$ \\
\hline ARENA & 5.432 .927 & 1,57 & 8.531 .122 & 48.276 .437 & 39.745 .315 & 8.743 .969 & 31.001 .346 \\
\hline DGATE & 342.889 & 1,57 & 538.425 & 34.398 .279 & 33.859 .854 & 7.449 .168 & 26.410 .686 \\
\hline FONET & 6.696 .556 & 1,57 & 10.515 .350 & 18.651 .174 & 8.135 .824 & 1.789 .881 & 6.345 .943 \\
\hline LOGO & 30.052 .136 & 1,57 & 47.189 .742 & 92.663 .596 & 45.473 .854 & 10.004 .248 & 35.469 .606 \\
\hline SMART & 769.909 & 1,57 & 1.208 .959 & 5.635 .083 & 4.426 .124 & 973.747 & 3.452 .377 \\
\hline LINK & 346.608 & 1,57 & 544.266 & 10.517 .006 & 9.972 .740 & 2.194 .003 & 7.778 .738 \\
\hline DESPC & 240.678 & 1,57 & 377.928 & 22.987 .302 & 22.609 .374 & 4.974 .062 & 17.635 .312 \\
\hline ARMDA & 9.745 .479 & 1,57 & 15.302 .960 & 27.035 .578 & 11.732 .618 & 2.581 .176 & 9.151 .442 \\
\hline ARDYZ & 5.900 .362 & 1,57 & 9.265 .116 & 38.375 .358 & 29.110 .242 & 6.404 .253 & 22.705 .988 \\
\hline PAPIL & 833.659 & 1,57 & 1.309 .063 & 17.335 .352 & 16.026 .289 & 3.525 .783 & 12.500 .505 \\
\hline ESCOM & 79.236 & 1,57 & 124.421 & 2.840 .963 & 2.716 .542 & 597.639 & 2.118 .903 \\
\hline KFEIN & 4.433 .503 & 1,57 & 6.961 .764 & 25.534 .429 & 18.572 .665 & 4.085 .986 & 14.486 .679 \\
\hline KRONT & 5.070 .789 & 1,57 & 7.962 .470 & 8.379 .430 & 416.960 & 91.731 & 325.229 \\
\hline ALCTL & 6.952 .650 & 1,57 & 10.917 .485 & 31.515 .425 & 20.597 .940 & 4.531 .547 & 16.066 .393 \\
\hline INDES & 40.095 .207 & 1,57 & 62.959 .999 & 181.020 .398 & 118.060 .399 & 25.973 .288 & 92.087 .111 \\
\hline
\end{tabular}

Tablo 3'e göre brüt ek kazanç tutarı en yüksek işletme INDES, en düşük işletme ise KRONT'dur. Aynı zamanda INDES en yüksek maddi varlık ortalamasına sahip işletmedir. Brüt ek kazanç tutarından vergi tutarı düşüldükten sonra bulunan net ek kazanç tutarında en yüksek değere sahip işletme değişmemiş ve INDES olmuştur. Analizin son aşamasında işletmelerin net ek kazanç tutarları ortalama sermaye maliyetlerine bölünerek entelektüel sermayeleri hesaplanmıştır. Bu doğrultuda öncelikle ağırlıklı ortalama sermaye maliyetinin (AOSM) belirlenmesi için aşağıda yer alan formül kullanılmıştır.

$\mathrm{AOSM}=($ Borç Oranı*Borç Maliyeti $)+($ Özsermaye Oranı*Özsermaye Maliyeti $)$ 
AOSM hesaplama formülünde yer aldığı üzere öncelikle işletmelerin borç oranları ve özsermaye oranları hesaplanmıştır. Ardından finansman giderlerinin borç tutarlarına bölünmesi ile borç maliyetleri bulunmuştur. Hesaplanmasında yaşanan zorluk nedeniyle ve elde edilen sonuçların karşılaştırılabilir olması amacıyla çalışmada, Tayfun Deniz Kuğu (2016) tarafından bilişim sektörü üzerine yapılan çalışmada kullanılan \%20 özsermaye maliyeti esas alınmıştır. Son olarak işletmelerin ağırlıklı ortalama özsermaye ve borç maliyetleri hesaplanmış ve bu iki tutar toplanarak ağırlıklı ortalama sermaye maliyetleri (AOSM) bulunmuştur.

Tablo 4'te, işletmelerin özsermaye oranları ile özsermaye maliyetleri çarpılarak elde edilen ağırlıklı ortalama özsermaye maliyetlerini ve borç oranları ile borç maliyetleri çarpılarak elde edilen ağırlıklı ortalama borç maliyetleri yer almaktadır. Ağırlıklı ortalama özsermaye maliyetleri ve ağıllıklı ortalama borç maliyetlerinin toplanması ile hesaplanan AOSM, 2018, 2019 ve 2020 yılları için ayrı ayrı ve ilgili üç yıl için ortalama hesaplanarak gösterilmiştir.

Tablo 4: Ağırlık Ortalama Sermaye Maliyetleri

\begin{tabular}{|c|c|c|c|c|c|c|c|c|c|c|c|c|}
\hline ARENA & $\begin{array}{l}\text { Borç } \\
\text { Tutarı } \\
\text { (a) }\end{array}$ & $\begin{array}{c}\text { ÖS } \\
\text { Tutarı } \\
\text { (b) }\end{array}$ & $\begin{array}{c}\text { Kaynak } \\
\text { Toplamı } \\
\text { (c) }\end{array}$ & $\begin{array}{l}\text { Borc } \\
\text { Oranı } \\
\text { (a) / (c) }\end{array}$ & $\begin{array}{c}\text { ÖS } \\
\text { Oranı } \\
\text { (b) / (c) }\end{array}$ & $\begin{array}{c}\text { Finansman } \\
\text { Gideri } \\
\text { (d) }\end{array}$ & $\begin{array}{c}\text { Borç } \\
\text { Maliyeti } \\
\text { (d) / (a) }\end{array}$ & $\begin{array}{c}\text { ÖS } \\
\text { Maliyeti }\end{array}$ & $\begin{array}{c}\text { AO } \\
\text { ÖS } \\
\text { Maliyeti }\end{array}$ & $\begin{array}{c}\text { AO } \\
\text { Borç } \\
\text { Maliyeti }\end{array}$ & AOSM & $\begin{array}{c}2018- \\
2020 \\
\text { AOSM }\end{array}$ \\
\hline 2018 & 540.727 .047 & 368.288 .239 & 909.015 .286 & 0,595 & 0,405 & 29.143 .746 & 0,054 & 0,20 & 0,081 & 0,032 & 0,113 & \multirow{3}{*}{0,112} \\
\hline 2019 & 747.583 .679 & 444.651 .315 & 1.192.234.994 & 0,627 & 0,373 & 41.860 .268 & 0,056 & 0,20 & 0,075 & 0,035 & 0,110 & \\
\hline 2020 & 1.082 .715 .945 & 583.749 .804 & 1.666.465.749 & 0,650 & 0,350 & 72.641 .827 & 0,067 & 0,20 & 0,070 & 0,044 & 0,114 & \\
\hline \multicolumn{13}{|l|}{ DGATE } \\
\hline 2018 & 170.057 .243 & 178.050 .702 & 348.107 .945 & 0,489 & 0,511 & 1.735 .448 & 0,010 & 0,20 & 0,102 & 0,005 & 0,107 & \multirow{3}{*}{0,106} \\
\hline 2019 & 223.522 .063 & 202.037 .941 & 425.560 .004 & 0,525 & 0,475 & 5.956 .758 & 0,027 & 0,20 & 0,095 & 0,014 & 0,109 & \\
\hline 2020 & 323.943 .235 & 187.214 .883 & 511.158 .118 & 0,634 & 0,366 & 14.703 .162 & 0,045 & 0,20 & 0,073 & 0,029 & 0,102 & \\
\hline \multicolumn{13}{|l|}{ FONET } \\
\hline 2018 & 20.297 .582 & 52.597 .045 & 72.894 .627 & 0,278 & 0,722 & 649.478 & 0,032 & 0,20 & 0,144 & 0,009 & 0,153 & \multirow{3}{*}{0,169} \\
\hline 2019 & 12.408 .946 & 66.912 .584 & 79.321 .530 & 0,156 & 0,844 & 535.702 & 0,043 & 0,20 & 0,169 & 0,007 & 0,175 & \\
\hline 2020 & 13.859 .317 & 94.871 .675 & 108.730 .992 & 0,127 & 0,873 & 559.537 & 0,040 & 0,20 & 0,175 & 0,005 & 0,180 & \\
\hline \multicolumn{13}{|l|}{ LOGO } \\
\hline 2018 & 244.584 .638 & 318.573 .563 & 563.158 .201 & 0,434 & 0,566 & 11.239 .814 & 0,046 & 0,20 & 0,113 & 0,020 & 0,133 & \multirow{3}{*}{0,123} \\
\hline 2019 & 381.131 .266 & 394.601 .006 & 775.732 .272 & 0,491 & 0,509 & 12.931 .385 & 0,034 & 0,20 & 0,102 & 0,017 & 0,118 & \\
\hline 2020 & 559.769 .916 & 537.750 .060 & 1.097 .519 .976 & 0,510 & 0,490 & 20.590 .005 & 0,037 & 0,20 & 0,098 & 0,019 & 0,117 & \\
\hline \multicolumn{13}{|l|}{ SMART } \\
\hline 2018 & 45.798 .130 & 27.610 .410 & 73.408 .540 & 0,624 & 0,376 & 2.140 .151 & 0,047 & 0,20 & 0,075 & 0,029 & 0,104 & \multirow{3}{*}{0,203} \\
\hline 2019 & -18.009 .798 & 61.698 .024 & 43.688 .226 & $-0,412$ & 1,412 & 2.132 .449 & $-0,118$ & 0,20 & 0,282 & 0,049 & 0,331 & \\
\hline 2020 & 16.105 .637 & 65.214 .841 & 81.320 .478 & 0,198 & 0,802 & 1.086 .028 & 0,067 & 0,20 & 0,160 & 0,013 & 0,174 & \\
\hline \multicolumn{13}{|l|}{ LINK } \\
\hline 2018 & 3.813 .822 & 27.991 .595 & 31.805 .417 & 0,120 & 0,880 & 2.198 .524 & 0,576 & 0,20 & 0,176 & 0,069 & 0,245 & \multirow{3}{*}{0,225} \\
\hline 2019 & 5.713 .402 & 34.708 .590 & 40.421 .992 & 0,141 & 0,859 & 1.452 .808 & 0,254 & 0,20 & 0,172 & 0,036 & 0,208 & \\
\hline 2020 & 5.886 .251 & 45.506 .631 & 51.392 .882 & 0,115 & 0,885 & 2.377 .972 & 0,404 & 0,20 & 0,177 & 0,046 & 0,223 & \\
\hline \multicolumn{13}{|l|}{ DESPC } \\
\hline 2018 & 42.021 .959 & 77.437 .579 & 119.459 .538 & 0,352 & 0,648 & 7.314 .831 & 0,174 & 0,20 & 0,130 & 0,061 & 0,191 & \multirow{3}{*}{0,146} \\
\hline 2019 & 73.143 .160 & 77.889 .984 & 151.033 .144 & 0,484 & 0,516 & 3.892 .197 & 0,053 & 0,20 & 0,103 & 0,026 & 0,129 & \\
\hline 2020 & 179.152 .836 & 98.048 .527 & 277.201 .363 & 0,646 & 0,354 & 13.566 .006 & 0,076 & 0,20 & 0,071 & 0,049 & 0,120 & \\
\hline \multicolumn{2}{|l|}{ ARMDA } & & & & & & & & & & & \\
\hline
\end{tabular}




\begin{tabular}{|c|c|c|c|c|c|c|c|c|c|c|c|c|}
\hline 2018 & 644.014 .741 & 229.391 .064 & 873.405 .805 & 0,737 & 0,263 & 45.592 .256 & 0,071 & 0,20 & 0,053 & 0,052 & 0,105 & \multirow{3}{*}{0,088} \\
\hline 2019 & 829.977 .390 & 272.497 .757 & 1.102 .475 .147 & 0,753 & 0,247 & 43.016 .045 & 0,052 & 0,20 & 0,049 & 0,039 & 0,088 & \\
\hline 2020 & 1.378 .760 .704 & 353.887 .498 & 1.732 .648 .202 & 0,796 & 0,204 & 52.735 .276 & 0,038 & 0,20 & 0,041 & 0,030 & 0,071 & \\
\hline \multicolumn{2}{|c|}{ ARDYZ } & & & & & & & & & & & \\
\hline 2018 & 20.726 .459 & 46.113 .712 & 66.840 .171 & 0,310 & 0,690 & 1.963 .698 & 0,095 & 0,20 & 0,138 & 0,029 & 0,167 & \multirow{3}{*}{0,180} \\
\hline 2019 & 16.389 .266 & 72.549 .011 & 88.938 .277 & 0,184 & 0,816 & 1.760 .249 & 0,107 & 0,20 & 0,163 & 0,020 & 0,183 & \\
\hline 2020 & 20.661 .817 & 173.520 .977 & 194.182 .794 & 0,106 & 0,894 & 1.998 .937 & 0,097 & 0,20 & 0,179 & 0,010 & 0,189 & \\
\hline \multicolumn{2}{|c|}{ PAPIL } & & & & & & & & & & & \\
\hline 2018 & 2.932 .239 & 59.425 .567 & 62.357 .806 & 0,047 & 0,953 & 325.436 & 0,111 & 0,20 & 0,191 & 0,005 & 0,196 & \multirow{3}{*}{0,214} \\
\hline 2019 & 9.701 .491 & 82.595 .334 & 92.296 .825 & 0,105 & 0,895 & 3.101 .727 & 0,320 & 0,20 & 0,179 & 0,034 & 0,213 & \\
\hline 2020 & 4.563 .388 & 90.063 .303 & 94.626 .691 & 0,048 & 0,952 & 4.198 .091 & 0,920 & 0,20 & 0,190 & 0,044 & 0,235 & \\
\hline \multicolumn{2}{|c|}{ ESCOM } & & & & & & & & & & & \\
\hline 2018 & 2.232 .799 & 74.324 .148 & 76.556 .947 & 0,029 & 0,971 & 22.393 & 0,010 & 0,20 & 0,194 & 0,000 & 0,194 & \multirow{3}{*}{0,206} \\
\hline 2019 & 2.590 .751 & 59.584 .009 & 62.174 .760 & 0,042 & 0,958 & 963.327 & 0,372 & 0,20 & 0,192 & 0,015 & 0,207 & \\
\hline 2020 & 3.259 .768 & 92.792 .234 & 96.052 .002 & 0,034 & 0,966 & 2.215 .387 & 0,680 & 0,20 & 0,193 & 0,023 & 0,216 & \\
\hline \multicolumn{2}{|c|}{ KFEIN } & & & & & & & & & & & \multirow{4}{*}{0,169} \\
\hline 2018 & 26.928 .082 & 83.550 .323 & 110.478 .405 & 0,244 & 0,756 & 2.059 .749 & 0,076 & 0,20 & 0,151 & 0,019 & 0,170 & \\
\hline 2019 & 27.748 .578 & 131.380 .929 & 159.129 .507 & 0,174 & 0,826 & 3.319 .095 & 0,120 & 0,20 & 0,165 & 0,021 & 0,186 & \\
\hline 2020 & 98.381 .581 & 228.821 .324 & 327.202 .905 & 0,301 & 0,699 & 3.518 .254 & 0,036 & 0,20 & 0,140 & 0,011 & 0,151 & \\
\hline \multicolumn{2}{|c|}{ KRONT } & & & & & & & & & & & \multirow{4}{*}{0,180} \\
\hline 2018 & 13.663 .928 & 41.668 .657 & 55.332 .585 & 0,247 & 0,753 & 2.739 .561 & 0,200 & 0,20 & 0,151 & 0,050 & 0,200 & \\
\hline 2019 & 25.309 .815 & 51.678 .075 & 76.987 .890 & 0,329 & 0,671 & 2.169 .758 & 0,086 & 0,20 & 0,134 & 0,028 & 0,162 & \\
\hline 2020 & 42.229 .816 & 59.515 .119 & 101.744 .935 & 0,415 & 0,585 & 6.164 .234 & 0,146 & 0,20 & 0,117 & 0,061 & 0,178 & \\
\hline \multicolumn{2}{|c|}{ ALCTL } & & & & & & & & & & & \multirow{4}{*}{0,086} \\
\hline 2018 & 352.156 .069 & 299.490 .883 & 651.646 .952 & 0,540 & 0,460 & 5.344 .135 & 0,015 & 0,20 & 0,092 & 0,008 & 0,100 & \\
\hline 2019 & 513.457 .651 & 298.649 .422 & 812.107 .073 & 0,632 & 0,368 & 11.160 .621 & 0,022 & 0,20 & 0,074 & 0,014 & 0,087 & \\
\hline 2020 & 784.039 .149 & 428.611 .534 & 1.212 .650 .683 & 0,647 & 0,353 & 319.192 & 0,000 & 0,20 & 0,071 & 0,000 & 0,071 & \\
\hline \multicolumn{2}{|c|}{ INDES } & & & & & & & & & & & \multirow{4}{*}{0,096} \\
\hline 2018 & 1.143.235.394 & 495.031 .892 & 1.638.267.286 & 0,698 & 0,302 & 90.917 .387 & 0,080 & 0,20 & 0,060 & 0,055 & 0,116 & \\
\hline 2019 & 1.848 .431 .009 & 568.307 .841 & 2.416 .738 .850 & 0,765 & 0,235 & 97.134 .616 & 0,053 & 0,20 & 0,047 & 0,040 & 0,087 & \\
\hline 2020 & 3.394 .442 .947 & 666.930 .195 & 4.061 .373 .142 & 0,836 & 0,164 & 213.324 .766 & 0,063 & 0,20 & 0,033 & 0,053 & 0,085 & \\
\hline
\end{tabular}

Tablo 4'e göre üç yıllık AOSM ortalaması en yüksek işletme 0,225 ortalama ile LINK olmuştur. AOSM ortalaması 0,20'nin üzerinde olan diğer ilk diğer işletmeler sırasıyla PAPIL, ESCOM ve SMART olmuştur.

İşletmelerin ağırlıklı ortalama sermaye maliyetlerinin hesaplanmasının ardından yöntemin son aşamasına geçilmiştir. İşletmelerin net ek kazanç tutarları üç yıllık AOSM’ne bölünerek entelektüel sermayeleri hesaplanmıştır.

Tablo 5: Entelektüel Sermaye Değerleri

\begin{tabular}{|l|c|c|c|}
\hline \multirow{2}{*}{ ARENA } & Net Ek Kazanç & AOSM & Entelektüel Sermaye \\
\cline { 2 - 4 } DGATE & (a) & (b) & (a) / (b) \\
\hline FONET & 31.001 .346 & 0,112 & 276.797 .733 \\
\hline LOGO & 26.410 .686 & 0,106 & 249.157 .417 \\
\hline SMART & 6.345 .943 & 0,169 & 37.549 .957 \\
\hline LINK & 35.469 .606 & 0,123 & 288.370 .784 \\
\hline
\end{tabular}




\begin{tabular}{|l|c|c|c|}
\hline DESPC & 17.635 .312 & 0,146 & 120.789 .808 \\
\hline ARMDA & 9.151 .442 & 0,088 & 103.993 .657 \\
\hline ARDYZ & 22.705 .988 & 0,18 & 126.144 .380 \\
\hline PAPIL & 12.500 .505 & 0,214 & 58.413 .575 \\
\hline ESCOM & 2.118 .903 & 0,206 & 10.285 .935 \\
\hline KFEIN & 14.486 .679 & 0,169 & 85.719 .995 \\
\hline KRONT & 325.229 & 0,18 & 1.806 .827 \\
\hline ALCTL & 16.066 .393 & 0,086 & 186.818 .527 \\
\hline INDES & 92.087 .111 & 0,096 & 959.240 .739 \\
\hline SEKTÖR ORTALAMASI & & & 170.444 .552 \\
\hline
\end{tabular}

Tablo 5'e göre en yüksek entelektüel sermaye değeri INDES'e aittir. Bunu sırasıyla LOGO, ARENA ve DGATE takip etmektedir. KRONT ise sektördeki işletmeler arasında en düşük entelektüel sermaye oranına sahiptir.

\section{Sonuç}

Sanayi Devrimi ile başlayan Endüstri devrimleri, bilim ve teknolojinin gelişmesi, küreselleşme, internetin hayatımıza girmesi ve yaşanan dijital dönüşümün ardından Endüstri 4.0 uygulamaları ile ekonomik ve sosyal açıdan tüm toplumları etkilemiştir. Dünyanın küresel bir pazar haline geldiği günümüzde, işletmeler arası rekabet yıkıcı boyutlara ulaşmıştır. Rekabetin ve sürdürülebilirliğin ön koşulu ise Endüstri 4.0’’n çıktısı kabul edilen entelektüel sermayeyi etkin yönetebilme becerisidir. Dünyada piyasa değeri en büyük olan işletmelere bakıldığında, bu işletmelerin defter değerinin piyasa değerinden önemli ölçüde düşük olduğu görülmektedir. Bu farkın ise entelektüel sermayeden kaynaklandığı ifade edilmektedir. Ancak çok değerli olmasına rağmen entelektüel sermayenin işletmelerin finansal tablolarında yer almaması eleştiri konusu olmaktadır. Entelektüel sermayenin en yoğun olduğu sektörlerden biri de bilişim sektörüdür. Dijital dönüşüm ve Endüstri 4.0 uygulamalarının ardından dünyadaki dev şirketler sıralamasında en üst sıralarda bilişim şirketleri yer almaktadır. Bu nedenle ülkemizde de bilişim sektöründe yaratılan entelektüel sermayenin görünür hale gelmesi açısından ölçülmesi ve yıllar itibari ile gelişimi önem arz etmektedir.

BİST’e kayıtlı bilişim sektöründe faaliyet gösteren 18 işletmenin entelektüel sermayelerinin ölçüldüğü çalışmada, işletme ve sektörün yıllar itibariyle ortalamalarını esas alan ve etkili bir ölçüm yöntemi olan hesaplanmış maddi olmayan değer yöntemi kullanılmıştır. VÖK ortalaması ile maddi varlık ortalamasının bölünmesi suretiyle ortaya çıkan maddi varlık kazanç oranı hem işletme hem de sektör bazında hesaplanmıştır. Sektörün maddi varlık kazanç oranı ortalamasının altında kalan PKART, NETAS ve KAREL değerlendirme dışı bırakılarak analize 15 işletme ile devam edilmiştir. Hesaplanmış maddi olmayan değer yönteminin kuralı gereğince VÖK’ü negatif olan işletmelerin de analiz dışı bırakılması gerekmektedir. Ancak çalışmada NETAS dışında negatif VÖK’e sahip bir işletme bulunmamaktadır. Bu nedenle yöntemin sonraki aşamaları 15 işletme ile tamamlanabilmiştir.

Bilişim sektöründe yer alan işletmelerden bazıları üretim, bazıları üretim ve ticaret, bazıları ise yazılım ve donanım üzerinde yoğunlaşarak faaliyet göstermektedir. Bu durum maddi ve maddi olmayan duran varlıklarının tutarında önemli ölçüde farklılıklar yaratmaktadır. Çalışmada dikkat çeken başka bir husus ise maddi varlık ortalamaları ile entelektüel sermaye değeri arasında oluşan ters yönlü ilişkidir. Sektörün maddi varlık kazanç oranı ortalamasının altında kalan NETAS ve KAREL en yüksek maddi varlık ortalamasına sahip işletmelerdir. En yüksek entelektüel sermaye değerine sahip bulunan INDES, LOGO, ARENA ve DGATE maddi varlık ortalaması açısından yüksek bir değere sahip değildir. Bu durumda ilgili işletmelerin maddi olmayan varlık tutarlarının sektördeki diğer işletmelere göre nispeten daha fazla olduğu ifade edilebilir.

Bilişim sektöründeki işletmelerin entelektüel sermayelerini hesaplanmış maddi olmayan değer yöntemi ile ölçen Kuğu, çalışmasında 2013 ve 2015 yılları arasındaki 3 yıllık döneme ait 14 şirketin finansal tablolarını analize dâhil etmiştir. Çalışmanın sonucunda tutar açısından sırasıyla sadece LINK, DGATE ve DESPEC için entelektüel sermaye hesaplanabilmiştir. Diğerleri çeşitli kısıtlar nedeni ile analiz dışında kalmışlardır. 2015 yılından 2020 yılına gelindiğinde 
bilişim sektöründe entelektüel sermayesi tutar olarak hesaplanan şirket sayısının 3'ten 15’e yükseldiği görülmektedir. Çalışmanın uygulama kısmındaki bulgular önceki çalışmalar ile karşılaştırıldığında bilişim sektöründe entelektüel sermayenin çok daha önemli hale geldiği söylenebilir. Yaşanan bu artışın, dünyada hızla yayılan Endüstri 4.0 uygulamalarının ülkemizde de takip edilmeye başlanmasından kaynaklandığı düşünülmektedir. 2017 yılında Bilim, Sanayi ve Ticaret Bakanlığı'nın Endüstri 4.0 sürecine ilişkin gerçekleştirdiği duyuru ve çalışmalar bu konuda yol haritasını belirlemiştir. Bilgi yoğun üretim gerçekleştiren bilişim sektörü de çağın ihtiyaçlarına en kolay adapte olan sektörlerden biri olup, sektörde yer alan şirketler tarafından bu dönemde entelektüel sermayeye yatırım yapıldığı düşünülmektedir. Günümüzün yıkıcı rekabet koşullarında, sürdürülebilir rekabet avantajının ön koşulu olan entelektüel sermaye varlığının gelişmesinin bilişim sektörü açısından son derece önemli olduğu söylenebilir.

Entelektüel sermaye varlı̆̆ı, ölçüm zorlukları nedeni ile finansal tablolarda raporlanamamaktadır. Ancak günümüzde çok önemli hale gelen entelektüel sermayenin raporlanamaması, finansal tablo kullanıcılarının işletme değerini belirlerken ve işletme ile ilgili verecekleri kararlarda yanılmalarına neden olabilecek düzeydedir. Çalışmada sektör maddi duran varlık ortalaması 20.212.865 TL olarak tespit edilmişken, entelektüel sermaye varlığı hesaplanan işletmelerin, entelektüel sermaye ortalaması 170.444.552 TL olarak hesaplanmıştır. Bu nedenle uygun bir değerleme yöntemi ile entelektüel sermaye varlığının finansal tablolara alınması ile ilgili çalışmaların başlatılmasının son derece önemli olduğu, muhasebe standartlarını düzenleyen kurumların bu konuda çalışma yapması gerektiği düşünülmektedir.

Yapılan analizin bilişim sektörü ile sınırlı tutulması ve kullanılan yöntem gereğince yalnızca üç yıllık dönemi kapsaması çalışmanın kısııını oluşturmaktadır. Ancak çalışma sonucunda elde edilen bulgular, daha sonra yapılacak olan çalışmalarda işletmelerin finansal performanslarına etkisinin ve firma değeri ile ilişkisinin ölçülmesi açısından yol gösterici olacaktır. Aynı zamanda sunulan veriler ile entelektüel sermayenin ölçümü için kullanılan diğer yöntemlerin de uygulanması gelecekteki çalışmalar için karşılaştırılabilirliği arttıracaktır.

Hakem Değerlendirmesi: Dış bağımsız.

Çıkar Çatışması: Yazarlar çıkar çatışması bildirmemiştir.

Etik Komite Onayı: Bu çalışma için etik komite onayı Arel Üniversitesi Etik Kurulu’ndan alınmıştır (Tarih:02.10.2020)

Finansal Destek: Yazarlar bu çalışma için finansal destek almadığını beyan etmiştir.

Yazar Katkıları: Çalışma Konsepti/Tasarım- İ.E.; Veri Toplama- İ.Ö.; Veri Analizi/Yorumlama- İ.E., İ.Ö.; Yazı Taslağı- İ.E., İ.Ö.; İçeriğin Eleştirel İncelemesi- İ.E.; Son Onay ve Sorumluluk- İ.E., İ.Ö.

Peer-review: Externally peer-reviewed.

Conflict of Interest: The authors have no conflict of interest to declare.

Ethics Committee Approval: This study was approved by the Arel University Ethics Committee (Date:02.10.2020).

Grant Support: The authors declared that this study has received no financial support.

Author Contributions: Conception/Design of Study- İ.E.; Data Acquisition- İ.Ö.; Data Analysis/Interpretation- İ.E., İ.Ö.; Drafting Manuscript- İ.E., İ.Ö.; Critical Revision of Manuscript- İ.E.; Final Approval and Accountability- İ.E., İ.Ö.

\section{Kaynaklar}

Akyüz, K.C. (2021). Orman ürünleri sanayi sektöründe hesaplanmış maddi olmayan değer yöntemi ile entelektüel sermayenin hesaplanmas1. Bartın Orman Fakültesi Dergisi, 23(2), 555-564.

Altuk Özden, V. E. (2018). Endüstri 4.0 ve uluslararası finansal raporlama standartlarına etkileri. Süleyman Demirel Üniversitesi İktisadi ve İdari Bilimler Fakültesi Dergisi, Endüstri 4.0 ve Örgütsel Değişim Özel Sayısı. 23, 1639-1650.

Aslanoğlu, S. \& Zor, İ. (2006). Bilgi varlıklarının değerlemesi: entelektüel sermaye ölçüm ve değerleme modelleri; karşılaştırmalı bir analiz. Muhasebe ve Finansman Dergisi, 29, 152-165.

Barut, A. \& Karabayır, M. E. \& Torusdağ, M. (2019). Entelektüel sermaye - firma değeri ilişkisi: Borsa İstanbul'da ampirik bir analiz. Çankırı Karatekin Üniversitesi IIIBF Dergisi, 9(1), 169-194.

Bölükbaşı, Y. (2014). Entelektüel sermayenin işletme bazında ölçülmesinde kullanılan yöntemler ve sigorta sektöründe bir araştırma. Marmara Üniversitesi İIBF Dergisi, 36(1), 425-447. 
Cabrita, M.R., Cruz-Machado, V. \& Duarte, S. (2019) Enhancing the Benefits of Industry 4.0 from Intellectual Capital: A Theoretical Approach. In: Xu J., Cooke F., Gen M. \& Ahmed S. (eds) Proceedings of the Twelfth International Conference on Management Science and Engineering Management. ICMSEM 2018. Lecture Notes on Multidisciplinary Industrial Engineering. Springer, Cham. https://doi. org/10.1007/978-3-319-93351-1_124

Çetin A., (2005). Entelektüel sermaye ve ölçülmesi. Marmara Üniversitesi İ̈BF Dergisi, 20(1), 359-378.

Derdiyok, T., Doğru, Ç. \& Ünal, S. (2020). Dijital çağda entelektüel sermayenin dönüşümü ve şirketlerin rekabet güçlerine etkileri. Ufuk Üniversitesi Sosyal Bilimler Enstitüsü Dergisi.9(18), 7-26. Retrieved from https://dergipark.org.tr/tr/pub/ufuksbedergi/issue/60189/873191

Eren, E. \& Akpınar, S. (2004). Yapısal sermayenin işletme performansı üzerindeki etkilerinin araştırılması, Öneri Dergisi. 6(22), 9-17. İşseveroğlu, G. \& Ercan, C. (2019). Entelektüel sermaye bileşenlerinin teknoloji şirketleri üzerine etkisi: BİST’ de ampirik bir uygulama. Muhasebe ve Finansman Dergisi, 83,111-130.

Garavan, T.N., Morley, M., Gunnigle, P. \& Collins, E. (2001). Human capital accumulation: The role of human resource development. Journal of European Industrial Training, 25(2), 48-68.

Kayalı, A.C., Yereli, A.N. \& Ada, Ş. (2007). Entelektüel katma değer katsayısı yöntemi kullanılarak entelektüel sermayenin firma değeri üzerindeki etkisinin belirlenmesine yönelik bir araştırma. Yönetim ve Ekonomi, 14(1), 67-90

Kesbiç Ozan, Ö. (2020). Türkiye ekonomisi açısından endüstri 4.0 ve rekabet gücü ilişkisi, Sosyal ve Beşerî Bilimler Araştırmalarl Dergisi, 21(47), 186-209.

KGK, TMS 38 Maddi Olmayan Duran Varlıklar, https://kgk.gov.tr

Kendirli, S. \& Konak,F. (2015). Entelektüel performansı üzerinde etkisi: Borsa İstanbul'da işlem gören bilişim şirketeri üzerine bir uygulama. Sakarya İktisat Dergisi, 4(1), 31-51.

Koç, F. \& Avc1, E. (2020). R\&D investments and intellectual capital: an application on BIST, Journal of Economics, Finance and Accounting (JEFA). 7(4), 374-391.

Kuğu, T.D., (2016). Hesaplanmış maddi olmayan değer yöntemi ile entelektüel sermayenin hesaplanması ve Borsa İstanbul'da bir uygulama. Journal of Human Sciences, 13(3), 4675-4684.

Kujansivu, P.\& Lönnqvist, A. (2007). Investigating the value and efficiency of intellectual capital, Journal of Intellectual Capital, 8(2), 272-287, https://doi.org/10.1108/14691930710742844.

Mavridis, Dimitrios G. (2004), Intellectual capital and its 1mpact on the performance of Greek listed firms. Review of Economic Sciences, 5, 159-176.

Mondal, A. (2016). Measuring the efficiency and value of intellectual capital in Indian knowledge companies, Journal of Commerce \& Accounting Research, 5(4), 10-17.

Pazarceviren, S. Y. \& Kaya, H. P. (2018). Entelektüel sermayeyi hesaplanmış maddi olmayan değer yöntemi ile ölçme ve raporlama. Business and Economics Research Journal, 9(2), 331-348.

Romanova, O.A., Berg, D.B. \& Matveeva Y.A. (2017). Creating competitive strategies of industrial enterprises from the standpoint of corporate social responsibility, Economic and Social Changes: Facts, Trends, Forecast,10(6), 138-152. DOI: 10.15838/esc/2017.6.54.9

Stewart, T.A. (1994). Your company’s most valuable asset: Intellectual capital. Fortune Journal, 130(7), 28-33.

Stewart, T. A. (1997). Entelektüel sermaye: Kuruluşların yeni zenginliği, Çeviren: Nurettin El Hüseyni, İstanbul: Kontent Kitabevi.

Sundac, D. \& Krmpotic, I. F. (2009). Measurement and management of intellectual capital. Tourism and Hospitality Management, 15, (2), 279-290.

Ulf, J. (1997). Mobilising change: charateristics of intangibles proposed by 11 Swedish firms, OECD International Symposium, Measuring and Reporting IC, Amsterdam.

Uyrun, A. \& Sanalan Bilici N. (2020). Entelektüel sermayeyi işletme bazında ölçen yöntemler ve hesaplanmış maddi olmayan değer yöntemiyle turizm sektöründe bir uygulama. Akademik Yaklaşımlar Dergisi. 11(2), 159-185. 
Uzay, Ş. \& Savaş, O. (2003). Entelektüel sermayenin ölçülmesi: Mobilya sektöründe karş1laştırmalı bir uygulama örneği. Erciyes Üniversitesi İktisadi ve İdari Bilimler Fakültesi Dergisi, 20, 163-181.

Volkov, D. \& Garanina, T. (2007). Intangible assets: Importance in the knowledge-based economy and the role in value creation of a company. Electronic Journal of Knowledge Management, 5(4), 539-550.

Yıldız, D. \& Genç, K. Y. (2019). Endüstri 4.0'ın entelektüel sermayedeki rolü: Ülkeler arası karşılaştırılması, Asya Studies-Academic Social Studies /Akademik Sosyal Araştırmalar, (10) Winter, 39-47.

Yıldız, D. \& Genç, K. Y. (2020). Entelektüel sermaye, inovasyon ve rekabet üstünlüğü, Ankara: Astana Yayınları Akademisyen Eğitim Danışmanlık Yayıncılık Hizmetleri A.Ş.

Yılmaz, B. \& Şahin İ. \& Güler E. (2005). Bilgi çağında entelektüel sermaye anlayışının muhasebe bilgi sistemi açısından değerlendirilmesi. Selçuk Üniversitesi Sosyal Bilimler Meslek Yüksekokulu Dergisi, 8(1-2), 91-99.

Yörük, N. \& Erdem, M.S. (2008). Entelektüel sermaye ve unsurlarının, İMKB’de işlem gören otomotiv sektörü firmalarının finansal performansı üzerine etkisi, Atatürk Üniversitesi İktisadi ve İdari Bilimler Dergisi, 22(2), 397-413.

Yuksel, A.N. \& Şener, E. (2017). The reflections of digitalization at organizational level: Industry 4.0 in Turkey. Journal of Business, Economics and Finance (JBEF), 6(3), 291-300. http://doi.org/10.17261/Pressacademia.2017.

Zor, İ. \& Cengiz S. (2013). Entelektüel sermaye ile firma değeri arasındaki ilişki: Borsa İstanbul'da bir araştırma. Çankırı Karatekin Üniversitesi İktisadi ve İdari Bilimler Fakültesi Dergisi, 3(1), 37-56. 